\title{
"The Pyrenees are not hollow": the mountain as a boundary object
}

\author{
"Os Pirineus não são ecos": a montanha como \\ objeto de fronteira
}

Jérôme Lamy

Pesquisador do Laboratoire Interdisciplinaire Solidarités, Société, Territoires/ Université Toulouse II Maison de la Recherche 5 Allées A. Machado 31058 Toulouse Cedex 9 jerome.lamy@laposte.net
LAMY, Jérôme. 'The Pyrenees are not hollow': the mountain as a boundary object. História, Ciências, Saúde - Manguinhos, Rio de Janeiro, v.16, n.3, jul.-set. 2009, p.789-801.

\section{Abstract:}

In Toulouse, around 1850, a controversy about the structure of the Pyrenees pitted observatory director Frederic Petit against geology professor Alexandre Leymerie. The object of the debate was an assumption formulated by Petit: that the inside of the Pyrenees was practically hollow. This proposal was based on work that Petit initiated in order to determine the latitude of Toulouse. The debates, which took place within the Toulouse Academy of Science and also in local newspapers, illustrate the organization of disciplinary spaces in the nineteenth century. Petit defended his research method based on calculation; the geologist's perspective was from the field. The emergence of the less mathematical science of geology came up against nineteenth-century astronomical practices, centered on calculation. Dissected by calculation or by visual observation, the mountain was an object of controversy from the perspective of distinct scientific practices.

Keywords: astronomy; geology; discipline; controversy; mountain.

\section{Resumo}

Em Toulouse, por volta de 1850, uma controvérsia sobre a estrutura dos Pirineus colocou o diretor do Observatório, Frederic Petit, contra o professor de geologia Alexandre Leymerie. O motivo do debate foi a hipótese formulada por Petit: o interior dos Pirineus era praticamente oco. A proposição baseava-se no trabalho que Petit iniciara para determinar a latitude de Toulouse. Os debates, que tiveram lugar na Academia de Ciências de Toulouse e também em periódicos locais, ilustram a organização dos espaços disciplinares no século XIX. Petit defendia seu método de pesquisa baseado em cálculos; a perspectiva do geólogo provinha do campo. A emergência da ciência geológica, menos matemática, vinha de encontro às práticas da astronomia daquele século. Analisada por cálculos ou pela observação visual, a montanha foi um objeto de controvérsia entre diferentes práticas científicas.

Palavras-chave: astronomia; geologia; disciplina; controvérsia; montanha. 
$\mathrm{T}$ his article analyzes the controversy between an astronomer and a geologist from Toulouse (France) concerning the Pyrenees. In 1849, astronomer Frédéric Petit determined the latitude of Toulouse using a pendulum. He discovered that the influence of the Pyrenees was negligible and concluded that the mountain was 'empty'. Geologist Alexandre Leymerie condemned this conclusion and defended geological methods for examining the inside of mountains.

This study takes as its starting point the question of disciplines. Recent works in science studies define a discipline as being "a collective dynamic that organizes epistemological, methodological, linguistic and organizational elements into a system" (Vinck, 2007, p.81). The production of articles submitted for the approval of peers constitutes its principal mechanism of inclusion and exclusion (Shinn, Ragouet, 2005; Gingras, 2003). A discipline is also a mode of regulating and transmitting scientific knowledge (Locher, 2006, p.193). Disciplines are subject to the "logic of fragmentation and combination" (Vinck, 2007, p.81); they are updated by structuring the tensions at their boundaries.

In this article, I try to understand how the disciplinary references and individual paths of Frédéric Petit and Alexandre Leymerie were articulated with respect to the mountain. In the first part I examine the career and disciplinary concepts of the astronomer and the geologist. In the second part, I detail the controversy between Petit and Leymerie. Lastly, I examine the limits of the concept of discipline as a tool for examining the production of knowledge.

\section{Astronomer versus geologist}

Frédéric Petit studied at the College Royal of Toulouse. After his baccalaureate in arts and sciences, he went to study in Paris. He was not accepted by Ecole Polytechnique, and failed the Agregation examination. He did, however, obtain two science degrees in 1833 and a doctorate in 1836. Petit presented two theses, the first relating to "the calculation of the effect of moving machines" and the second to "the earth moving around its center of gravity" (Gatien-Arnoult, 1866, p.643). He was François Arago's student and worked at the Paris Observatory. In 1838, Frédéric Petit was appointed director of the Toulouse Observatory on Arago's recommendation (Joly, 1866, p.5). This privileged access to the directorship aroused a certain hostility in Toulouse. The newspaper l'Emancipation denounced "the favoritism"1 of Frédéric Petit. Adolphe Gatien-Arnoult, arts professor at the Faculty of Toulouse, reproached Petit with his failure in competitive examinations and insisted that his nomination had been "arbitrary" ${ }^{2}$. Frédéric Petit refuted these charges systematically, while striving to affirm his scientific worth (Lamy, 2007, p.178).

Petit's training in astronomy included a lot of mathematics. His doctoral thesis, in particular, contained mathematical solutions to mechanical and astronomical problems. His later works were marked by the prevalence of calculation in scientific processes. His favorite subject of research concerned meteors. He tried to collect as much information as possible about their location, motion and duration with the aim of using mathematical principles to describe their trajectories. In 1849, he claimed to have developed "a method ... founded only on spherical trigonometry" (Petit, 1849a, p.53). However, the data he 
gathered were often not very reliable because of the transient nature of meteoric phenomena. Frédéric Petit used mathematical formalism to integrate pieces of information and tested observations in order to reduce their inaccuracies.

He subjected the observations "of successive modifications ... to satisfy not only the mathematical conditions, but [also] the various physical circumstances of these observations" (Petit, 1844, p.308). He adjusted those "elements which appear more prone to errors". Petit's objective was not to describe "the real trajectory" (p.309), but to produce all the possible trajectories by calculating them. He was using mathematics to reduce observational uncertainties.

Another example may help to appreciate the primacy Frédéric Petit granted to mathematics in scientific processes. In July 1860, he observed an eclipse of the sun in Spain. The weather conditions were poor, but the astronomer nonetheless managed to send his results to the Paris Academy of Science. He explained in his conclusion why, in spite of the difficulties encountered, he had communicated "the mathematical part of [his] observation, as elements of control for the astronomical tables" (Petit, 1860, p.394). The poor quality of the visual observation was not an obstacle to mathematical formalization; the latter was a sufficient result in itself. This primacy of mathematics was central to Petit's particular attitude to the observational sciences, especially meteorology. He integrated this discipline into his corpus of practices. However, he took care to explain how meteorology differed from astronomy, maintaining that "the multiplicity, complication and instability of the causes which produce or modify weather phenomena will never make it possible to obtain regular laws as in astronomy" (Petit, 1847b, p.39). Meteorology produces data: if they are irreducible by mathematical formalism, they cannot produce predictive laws. For Frédéric Petit, there was a tacit hierarchy between disciplines, with their status depending on their proximity to mathematics and their ability to develop predictive laws.

This particular notion of astronomy was not widespread in France's astronomical community. As an example, we can see the changing opinion of François Arago on this point. In 1830, writing Fresnel's obituary, he recognized that it was only "in the hands of Newton" (Arago, 1854, p.126) that astronomical observations could be understood. Mathematical formalization was essential to understanding celestial movements. In 1853, however, Arago expressed a radically different point of view, distinguishing three major branches of astronomy. The first related to "observations made with the most delicate instruments for fixing the absolute positions of stars at a given time" (Arago, 1859, p.247). The second sector related to the "physical makeup of the stars." The third branch aimed "to determine analytically ... the direction and value of the disturbances" undergone by a star in its trajectory. Arago recognized that work using only "calculation and ... mathematical analysis has great importance", but should not be regarded as superior to observations (p.247). After Le Verrier's discovery of Neptune in 1846, Arago restored the priority of astronomy: the observation of stars and survey of positions.

Frédéric Petit's understanding of astronomy was outdated. Throughout his career, he attached importance to the primacy of mathematics. However, Petit and Arago did agree on the importance of observatories and their instrumentation to astronomical work. In 
his Astronomie populaire Arago (1872, p.787) claimed: "It is impossible to make important astronomical discoveries outside special establishments built to last and using delicate instruments". He added: "it is in great peace, far from any distraction, that it is possible to give observations all the precision which is required from now on for advancing knowledge" (p.782). Frédéric Petit fully supported his mentor's point of view. When he had his observatory built in Toulouse, he explained to the architect what he had to do: the specificity of an observatory required "taking account of the intimate composition of all the parts of the building" ${ }^{\prime 3}$. The plans must be "a faithful expression of astronomers' ideas." 4 The new establishment must house the "new instruments" that Petit gathered and whose precision could be measured only in a special construction. The observatory was also, for Petit, a place of "meditation and silence." ${ }^{6}$. Frédéric Petit associated an old notion of astronomy with a defense of the specificity of its place of research.

Alexandre Leymerie was a former student of the Ecole Polytechnique. He taught geometry and applied mechanics at the College of Troyes starting in 1827. He studied geology and mineralogy (Barthélémy, 1879, p.16). In 1833, he was appointed professor of mathematics at Ecole Industrielle de la Martinière in Lyon. Leymerie returned to Paris in 1837, where he attended lectures by geologist Leonce Elie de Beaumont, who exerted a great influence on geology in the first part of the 19th century. His conception of geological science shed light on the practices of his student, Leymerie, in Toulouse. Elie de Beaumont recognized in his Leçons de géologie pratique (1843-1844) that geology was "a science under construction" (Elie de Beaumont, 1845, p.33). It had developed greatly since the beginning of the 19th century and become more "precise" (p.8) frontiers" (Fabiani, 1988, p.97), to legitimize the position of geology alongside other sciences: he related it "to astronomy, geography, physics, and chemistry" (Elie de Beaumont, 1845, p.4), and also to meteorology and hydrography (p.5). Geology began where all these sciences "lost their precision" (p.4). In this manner, geology attained new levels of "rigor" (p.4). Alexandre Leymerie belonged to the generation of scientists who introduced the teaching of geology to French universities, trying to draw a distinction between geology and other disciplines.

Alexandre Leymerie defended his science doctorate in 1840. That same year, he obtained the chair in geology and mineralogy at the Science Faculty of Toulouse (Barthélémy, 1879, p.17). His teaching, before coming to the university, had been practical, even if it was based on mathematics. In writing Leymerie's obituary, A. Barthélémy (p.18) notes that this experience of teaching of the applied sciences developed his "clarity and his methodical mind". In Toulouse, his research essentially dealt with the Pyrenees (Leymerie, 1881, 1858).

His interest in this chain of mountains bordered on exaltation: "From the start, he felt attracted to the mountains. He became conscious of the work which he had to do and he tried to cast light on this chaos of shifts and undulations which make the Pyrenees a vast, still virtually unexplored field of study" (Barthélémy, 1879, p.18). By virtually sweeping aside former works by Déodat de Dolomieu and Raymond de Carbonnières, Leymerie positioned himself at the forefront of Pyrenean studies.

Leymerie's passion for and defense of the Pyrenees knew no bounds. In 1876, he went to Grenoble for a meeting of scientific societies, where he met his counterpart, Lory, who 
studied the Alps, a mountain range on which he heaped great praise. Leymerie "protested in the name of the Pyrenees, which he called the queen of the mountains," (Barthélémy, 1879 , p.19). His experience of the mountain was physical, almost carnal. Leymerie believed geology to require "particular physical qualities, the mens sana in corpore sano, that it had to the extreme" (p.17). His obituarist described Leymerie's bodily "hexis" (Bourdieu, 1981, p.117), incorporating the practice of hill-walking. His lean physique allowed the geologist "to easily climb mountains ..." (Barthélémy, 1879, p.17). Leymerie made many excursions "to further extend the field of his investigations" (p.19). Barthélémy comments that Leymerie was better in situ: "in the field, in the middle of rocks, ... he could imbue his demonstrations with true interest ..." (p.20). Qualified geologists tended to be chosen for their capacity to optimize their physical aptitude in the field. Leopold de Buch, the famous German geologist, wrote to Leymerie to congratulate him on his work on the Pyrenees. He praised him for his "observant eye" and his "sagacity" (Leymerie, 1869).

Léonce Elie de Beaumont (1845) described the peculiarities of geology: "One of the things that is particular to geology is the geologist's way of life," (p.27). Besides peer esteem and respect of the rules (p.10), geologists had to work "in the field" (p.27). It was there that they collected facts. Elie de Beaumont insisted on this capacity of the geologist to walk a long time in the hills (p.76), to merge into his surroundings (p.74), to maintain "great attention" (p.30).

In addition to particular physical qualities, geological research requires a significant level of intuition. For Leymerie's biographer, geology requires "the antique dealer's sense of smell to unearth the geological prize" (Barthélémy, 1879, p.17).

The specific aptitudes of the geologist, as Alexandre Leymerie conceived them, induced a particular conception of geology. In his Elements de minéralogie et de géologie (Leymerie, 1861) he noted that the science of "geology" had been a "conjectural science" for a long time: scientists had "only a small number of facts ... that were not enough ... to be used as a basis for a serious theory of the Earth" (p.265). The systems followed one another and thus involved "a certain disregard" for "geological investigations". But the work of Fuchsel, Hutton, Saussure and Werner made it possible to gather "many facts" (p.266). Leymerie insisted: it was a question of establishing "the bases of a true science of facts ..." (p.266). He admitted that "the theoretical or speculative part" of geology, based on observations, "became very sizeable" (p.266). He refused however to devote the whole of his work to theory, even though it might be "wise" (p.266). Leymerie preferred to scatter speculative elements throughout his texts. We can, then, see how the Toulouse geologist considered his discipline a science of facts, leaving little space for theory. On this point he was in agreement with Elie de Beaumont, his teacher, who also insisted that new geology "is based on observations [and] on facts" (Elie de Beaumont, 1845, p.24). In general terms, however, Leymerie was reluctant to follow original processes in science; "until his death he had an invincible horror of new theories" (Barthélémy, 1879, p.19).

Alexandre Leymerie conceived the relationship between geology and other scientific disciplines in hegemonic terms. For him, "geology is a great river which has physics, chemistry and even astronomy as its tributaries" (Barthélémy, 1879, p.17). In his Elements de minéralogie et de géologie, Leymerie specifically mentions the battle of wills between 
disciplines from the natural sciences. He complains bitterly "about the claim of paleontologists who want to control geology", but admits that "paleontology is a powerful auxiliary for geological science" (Leymerie, 1861, p.VII). He also annexed mineralogy to geology (Leymerie, 1861, p.265). Leymerie saw geology as holding a dominant position and making use of practical elements from subordinate disciplines.

Having described the careers and concepts of the disciplines of the astronomer and the geologist, we can now examine the controversy they were engaged in over the Pyrenees. We will see how the oppositions emphasized in the two portraits above were played out.

\section{Full versus hollow}

The object of the controversy was a hypothesis formulated on several occasions by the director of the Toulouse Observatory, according to which "the inside of the Pyrenees was totally empty," (Petit, 1849b, p.730).

The Toulouse astronomer, Petit, drew this daring conclusion from his work to determine "the latitude of the new observatory of Toulouse" (Petit, 1847a, p.257). He made "1608 observations, either of circumpolar stars, or of midday stars" (p.257). The astronomer specified that he had begun his work at the old observatory, but its serious construction defects forced Petit "to entirely start [his] research again at the new observatory" (Petit, 1850, p.168). Petit explained that oscillations of the pendulum were observed "with all the precautions necessary to ensure the success of this important determination" (p.168). He insisted at length on the quality of his instrumentation and the precision of the device. In a report submitted to the Academy of Science in 1849, Frédéric Petit compared the "latitude obtained by 1608 astronomical observations" and the "latitude deduced" (Petit, 1849b, p.729) using geodetic methods by his predecessor in 1820 . The astronomer observer found a "difference of -0' 9" (p.730), which he thought was an insignificant error of observation. He concluded that the deviation exerted by the mountain "should be null" (p.730). This last assertion meant for Petit that "the inside of the Pyrenees was almost totally empty" (p.730). Fired by enthusiasm at his discovery, the astronomer wrote a few years later to his friend Antoine d' Abbadie, explaining that astronomy realized what politics could not yet do, confirming the "famous words of Louis XIV: there are no more Pyrenees" ${ }^{8}$ The lack of attraction exerted by mountains had been noted by Pierre Bouguer (1749) on an expedition to Peru and also by Maskeline and Hutton. However, never had an astronomer deduced from this anomaly that mountains were hollow.

Frédéric Petit published his conclusion in the Compte Rendu de l'Académie des Sciences, and the Mémoires de l'Académie de Sciences, Inscriptions et Belles-Lettres de Toulouse. He also explained his findings in 1852 to the Scientific Congress of Toulouse, where they were very well received. ${ }^{9}$ This conclusion annoyed the professor of geology at the Science Faculty of Toulouse, Alexandre Leymerie. He wrote a "note to refute ... the assertion submitted by Mr. Petit" (Leymerie, 1853, p.285-286), which he read at a meeting of the Academy of Science of Toulouse. The exchanges between the two scientists were published in the Mémoires de l'Académie des Sciences, Inscriptions et Belles-Lettres in 1853 (Leymerie, 1853; Petit, 1853). 
Initially the controversy revolved around reciprocal charges of incompetence and disciplinary encroachment. Alexandre Leymerie thought that Frédéric Petit, by writing "that the Pyrenees were hollow", had undoubtedly forgotten some "traditional concepts" (Leymerie, 1853, p.287) which he proposed to remind Petit of. Leymerie wanted to give a "short refutation" to the thesis defended by the astronomer because "the consideration of geologists" (p.286) was at stake. In his response to Petit, Leymerie took care to position himself as a representative of the geological sciences and it is as such that he examined the work of the astronomer. In order to show that Petit had encroached into a field he did not master, the geologist taught him a true lesson in the "structure of mountains" (p.286). Leymerie explained that these reliefs everywhere followed "a general plan", having "in the center ... a solid core, which is usually of granite, and, on the plains, successive stratified layers ..." (p.286).

The geologist noted that the hypothesis of hollow Pyrenees failed to take account of certain valleys "which cut the mountains throughout their length," (Leymerie, 1853, p.286) without any cavities being visible. Alexandre Leymerie added that "an experienced geologist can follow ... all the strata on top of one another around the granite core without the least interruption ..." (p.286). Implicitly, Leymerie was pointing out that Petit lacked even elementary knowledge of geology and was incompetent. The astronomer had no grounds upon which to talk about the structure of the Pyrenees: this was the object of geological study.

In Petit's note that followed this virulent attack, the astronomer emphasized his opponent's weak astronomical knowledge. He noted from the start "a serious error" (Petit, 1853, p.290), because "no astronomer thought to determine longitude using experiments with a pendulum" (p.290-291). The geologist tried to rectify this sentence by substituting "the word latitude with the word longitude" (p.290 infra) in the printed version of his text. Frédéric Petit noted that this transformation "is not happy", saying that it was absurd to determine latitude with a pendulum. Special instruments were much more precise than pendulums (p.291 infra). Petit turned Leymerie's accusation of incompetence against him, emphasizing his poor knowledge of astronomy. He also pointed out Leymerie's disciplinary encroachment.

In order to give more weight to his arguments, Leymerie cited the names of prestigious scientists whose authority was indisputable in the scientific community. He explained that observations by Ramond, Carpenters and Dufrenoy condemned the theory put forward Frédéric Petit. These geologists "certainly did not work on a phantom of a mountain, but of course a massif, all of whose elements they recognized and which they examined into its greatest depths" (Leymerie, 1853, p.286-287). Lastly, Leymerie quoted the studies of Leonce Elie de Beaumont which made the Pyrenees "one of the most traditional mountain ranges in regard to its structure and the simplicity of its relief" (p.288). He hoped to put an end to the polemic by mentioning Elie de Beaumont, the most important geologist in France in the first part of the 19th century, but Petit retorted that "M. Elie de Beaumont ... is precisely the first" to whom he had presented his "peculiar result" (Petit, 1853, p.293). The astronomer explained that Elie de Beaumont, "after having reflected a few moments" (p.293), had urged him to make his theory known. In other words, Petit responded to 
Leymerie's name-dropping of prestigious scientists by showing that he himself was close to Elie de Beaumont, saying that he had been his student (p.293) and insisting on his closeness to Elie de Beaumont in an attempt to neutralize Alexandre Leymerie's attacks.

In the exchange, what seems to have counted most was not their reference to work validated by the scientific community, but their mention of prestigious names whose authority, more than their research, they hoped would silence their opponent. Here, the name of Elie de Beaumont could equally justify the arguments of Leymerie and those of Petit: it was only the geologist's fame that mattered.

The controversy between the two Toulouse scientists did not only relate to their respective competence in geology and astronomy; it was also the occasion of a fierce defense of their own scientific practices. Alexandre Leymerie invited Petit "to study the influence of the Pyrenees on the pendulum, not at the Observatory of Toulouse, but in the Pyrenees themselves" (Leymerie, 1853, p.288). By leaving the observatory and going into the field, the astronomer would logically "remark a very sensitive effect" and acquire "new proof in support of the geologists" (p.288). Frédéric Petit rejected his opponent's arguments, complaining of "the more or less rigorous geological considerations", which he opposed to his "numerical results" (Petit, 1853, p.290). Petit could accept arguments only if they were based on astronomical work. "As long as Mr. Leymerie does not destroy my 1608 observations of latitudes, ... by 1608 observations of a comparable nature ..., as long as he does not show ... that my analysis and my calculations on the attraction of the Pyrenees are completely false, I will be authorized to declare that his logic, as rigorous as it may appear to him, must necessarily fade away before the more rigorous logic ... of numbers ..." (p.289). He urged Leymerie to use his method and to attain exactitude by calculation. For him, geology could not be strict because as a discipline it stood on the fringes of the empire of numbers.

The Science Faculty put an end to the controversy and forbade the two scientists from debating in the Toulouse journals. ${ }^{10}$ Frédéric Petit also received a warning ${ }^{11}$ from the director of the Academy.

\section{Disciplinary cultures}

In his arguments, Frédéric Petit insisted that the rigor of his mathematical work outweighed any geological methods. He flaunted his knowledge of geology by mentioning his closeness to Elie de Beaumont. He also emphasized the importance of his instruments for gathering precise data. This defense of a highly mathematical astronomy was related to his peculiar local position. Frédéric Petit's scientific legitimacy had been called into question on his arrival in Toulouse, where he had to prove himself by developing an astronomy which gave primacy to calculations.



Frédéric Petit (1810-1865), Director of Toulouse Observatory from 1838 to 1865 (Archives Municipales de Toulouse) 
Alexandre Leymerie considered himself a specialist on the Pyrenees. He also defended his discipline and his object of research at a time, in the early 1800s, when geology was still an incipient scientific profession in France and was just starting to be organized and structured (e.g. Bulletin de la Société Géologique de France was created in 1830). Leymerie emphasized the rigor of his work, his methods and his attitude in the field. The Pyrenees were his chosen field, with which he had strong bonds. To understand the controversy between the astronomer and the geologist, the concept of disciplines is not sufficient. The position taken by Frédéric Petit differed from that of his master, Arago, who had stated: "geology is being integrated into the exact sciences" (Arago, 1872, p.72). Concerning the deviations of the pendulum near a mountain, Arago (1871, p.72) explained that "astronomers attributed too great a part to local attractions, and that they wanted to explain by those means any discrepancies" which were perhaps only "simple errors of observation".

To understand what was at stake in the debate between Petit and Leymerie, I shall repeat and extend Peter Galison's proposal to consider that within disciplines there are distinct cultures, such as the theoretical and experimental cultures within physics in the 20th century (Galison, 2002, p.251-271, 1997). I shall take a discipline as a matrix of references, defined by the scientific community as an ideal spectrum from which the scientists of this discipline draw methodological, practical and epistemological elements. With these elements, they build their own disciplinary culture according to their interests, their academic position and their local circumstances. This disciplinary culture respects the most important axes of the discipline, but may deviate in specific cases.

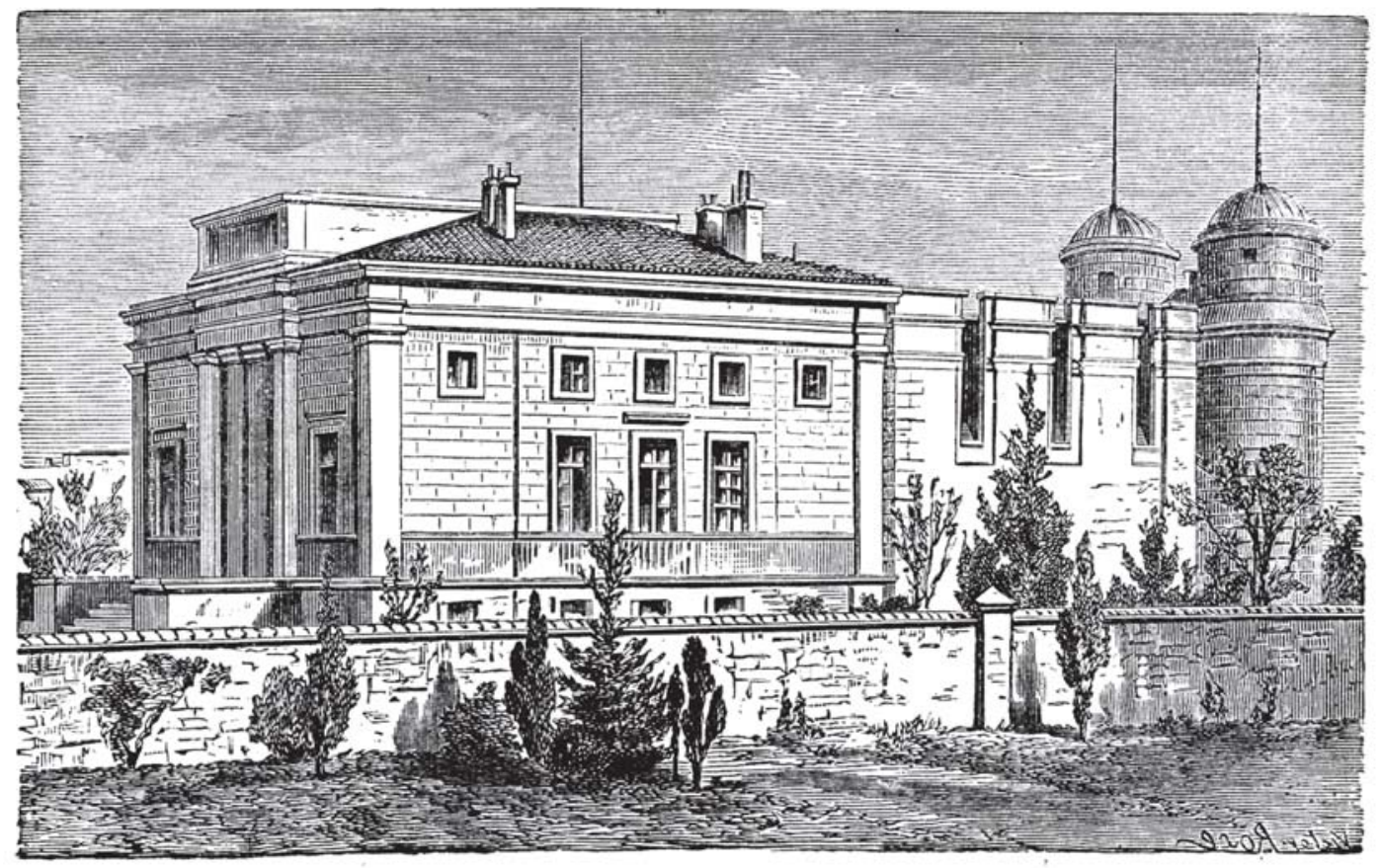

The Toulouse Observatory in 1857 (Archives Municipales de Toulouse, Guide illustré dans Toulouse et dans le département de la Haute-Garonne, Toulouse, Imprimerie Paul Privat, 1877, p.143-144) 
In Toulouse, Petit built his own astronomical culture, giving a disproportionate weight to mathematics and originality. He also considered the observatory an exclusive place of knowledge. This disciplinary culture was different from the disciplinary matrix which Arago, for example, developed in his writings. Frédéric Petit adapted and transformed the elements of the discipline of 'astronomy' according to his local circumstances. He had to defend his status as an astronomer in Toulouse because he was suspected of nepotism. So, he preserved the central role of the observatory in astronomical practice. This place, of which he was the supreme master, was the starting point of his research. In the same way, to counterbalance his failure in competitive examinations, he defended an obsolete mathematical astronomy (compared with the astronomy put forward by Arago), which nevertheless enabled him to use the rigor of numbers to contradict any opponents. By adopting original approaches (to meteors or the Pyrenees), he hoped for great recognition from the astronomy community.

Leymerie's disciplinary culture was close to the canons of the discipline of 'geology'. This was an incipient science and geologists had to defend their methods, their practices and the objects of their research. In his daily work, Leymerie integrated the geologist's 'way of life' and praised work 'in full field'. One can, however, note two significant variations from the bases of the discipline as Elie de Beaumont had conceived them. Leymerie proposed a hierarchy of disciplines which was topped by geology, while Elie de Beaumont's ambition had been to find 'points of contact' with other disciplines. Leymerie also appropriated the Pyrenees as his personal object of research. For the geologist, the point was to locally establish his firm authority in his scientific field.

We can understand the controversy between Petit and Leymerie not as a confrontation between two disciplines whose epistemological bases were totally irreconcilable, but as an opposition between two disciplinary cultures. These expressed local antagonisms: Petit had to defend his legitimacy in Toulouse; Leymerie wanted to protect his object of research. Each mobilized different elements, some of which belonged to their disciplines, while others were obsolete or transformed and others again were completely alien to them.

The two disciplinary cultures of Petit and Leymerie created two distinct and irreducible 'mountain' objects. The Pyrenees was a boundary object. They materialized 'local' recombination of the scientific field and 'local' constraints weighing on the production of knowledge.

This paper is a report on work in progress and is based on a specific case study: a controversy between a geologist and an astronomer from Toulouse University. Some of the assumptions in the paper are confronted with other case studies, in particular with regard to the importance of mountains in different fields. The discussion of the disciplines represented by the two scientists (their hierarchy, points of contact, boundary demarcations) is accompanied by updated notions of authority and legitimacy. Links between the fight for zones of knowledge and local recognition are strong, but I have to analyze other controversies concerning local objects to understand the question of scientific authority and its intrications with political power (especially when it is local). It is advisable to explore more precisely the emergence of geology as a scientific field in France in the 19th century. In forthcoming research, I will analyze the constitution of the scientific profession 
of the geologist (with its recruitment criteria, profesionnal associations, university chairs and reviews). Works by Martin Ruduwick (1996), Rachel Laudan (1977), Roy Porter (1976, 1978 , 1982) provide interesting tracks for exploring the case of French geology.

\section{ACKNOWLEDGEMENTS}

I thank Emmanuel Davoust for his help in translating this article.

\section{NOTES}

${ }^{1}$ Journal Politique et Littéraire de Toulouse et de la Haute-Garonne, Apr. 30, 1840, p.1.

${ }^{2}$ Gatien-Arnoult to the Journal Politique et Littéraire de Toulouse et de la Haute-Garonne, Apr. 30, 1840, p.1.

${ }^{3}$ Municipal Archives of Toulouse (MAT), 4D 95, Frédéric Petit to Armand Perpessac, Dec. 9, 1839.

${ }^{4}$ Idem.

${ }^{5}$ Annales de l'Observatoire de Toulouse, T. I, 1863, p.4.

${ }^{6}$ MAT, 1M 5, Frédéric Petit to the Mayor of Toulouse, Nov. 11, 1848.

${ }^{7}$ On the beginning of geology as a discipline, see: Rudwick, 1996 ; Laudan, 1977; Porter, 1976, 1978, 1982; and Greene, 1982.

${ }^{8}$ Castle of Abbadia Archives, box Astronomy and Geodesy, letter n.186, Frédéric Petit to Antoine d'Abbadie, 17 apr. 1862.

${ }^{9}$ Journal de Toulouse, Sept. 12, 1852.

${ }^{10}$ Journal de Toulouse, May 19, 1853.

${ }^{11}$ French National Archives, $\mathrm{F}^{17}$ 21476, Ministère de l'Instruction Publique, Renseignements confidentiels, 1865.

\section{REFERENCES}

ARAGO, François.

Astronomie populaire. t.III. Paris: L. Guérin et Cie. 1872.

ARAGO, François.

Astronomie populaire. t.IV. Paris: L. Guérin. 1871.

ARAGO, François.

Euvres Complètes. t.XI. Paris: Gide éditeur. 1859.

ARAGO, François.

CEuvres Complètes. t.I. Paris: Gide et Baudry éditeurs. 1854.

BARTHÉLÉMY, Alexandre.

Éloge de M. Leymerie. Mémoires de l'Académie des Sciences, Inscriptions et Belles-Lettres de Toulouse, Toulouse, 8. series, t.1, p.15-26. 1879.

BOUGUER, Pierre.

La figure de la Terre. Paris: Charles-Antoine Jombert. 1749.

BOURDIEU, Pierre.

Le sens pratique. Paris: Editions de Minuit. 1981.

ELIE DE BEAUMONT, Léonce.

Leçons de géologie pratique, professées au Collège de France pendant l'année scolaire 1843. Paris: P. Bertrand éditeur. 1845.

FABIANI, Jean-Louis.

Les philosophies de la république. Paris: Les Editions de Minuit. 1988.

GALISON, Peter.

Ainsi s'achèvent les expériences: la place des expériences dans la physique du $\mathrm{XX}^{\mathrm{e}}$ siècle. Paris: La Découverte. 2002.

GALISON, Peter.

Image and logic: material culture of microphysics. Chicago: University of Chicago Press. 1997.

GATIEN-ARNOULT, Adolphe. Éloge de Frédéric Petit. Mémoires de l'Académie Impériale des Sciences, Inscriptions et BellesLettres de Toulouse, Toulouse, 6. series, t.4, p.641-663. 1866.

GINGRAS, Yves. Mathématiques et exclusion: socio-analyse de la formation des cités savantes. In: Wunenburger, Jean-Jacques (Org.). Bachelard et l'épistémologie française. Paris: Presses Universitaire de France. p.115-152. 2003. 
GREENE, Mott T.

Geology in the nineteenth century: changing views in a changing World. Ithaca, London: Cornell University Press. 1982.

JOLY, Nicolas.

Extrait du Journal d'agriculture pratique et d'économie rurale pour le midi de la France. Toulouse: Imprimerie C. Douladoure. 1866.

LAMY, Jérôme.

L'Observatoire de Toulouse aux XVIII et XIX ${ }^{e}$ siècles: archéologie d'un espace savant. Rennes: Presses Universitaires de Rennes. 2007.

LAUDAN, Rachel.

Ideas and organizations in British geology: a case study in institutional history. Isis, Chicago, v.68, n.4, p.527-538. 1977.

LEYMERIE, Alexandre.

Description géologique et paléontologique des Pyrénées de la Haute-Garonne. Toulouse: Privat. 1881.

LEYMERIE, Alexandre.

Catalogue des travaux géologiques et minéralogiques publiés jusqu'en 1870. Paris: Masson et Baillière. 1869.

LEYMERIE, Alexandre.

Eléments de minéralogie et de géologie. Paris: Victor Masson, Louis Hachette et Cie. 1861.

LEYMERIE, Alexandre.

Esquisse géognostique des Pyrénées de la HauteGaronne, prodrome d'une carte géologique et d'une description de ce département. Toulouse: $\mathrm{L}$. Gimet et E. Privat. 1858.

LEYMERIE, Alexandre.

Les Pyrénées ne sont pas creuses: notes pour réfuter l'assertion contraire émise par M. Petit. Mémoires de l'Académie Impériale des Sciences, Inscriptions et Belles-Lettres de Toulouse, Toulouse, 4. series, t.2, p.285-288. 1853.

LOCHER, Fabien.

Configurations disciplinaires et sciences de

l'Observatoire: le cas des sciences de

l'atmosphère (XIX $\left.{ }^{\mathrm{e}}-\mathrm{XX}^{\mathrm{e}} \mathrm{s}\right)$. In: Boutier, Jean; Passeron, Jean-Claude; Revel, Jacques (Ed.). Qu'est-ce qu'une discipline. Paris: Editions de l'Ecole des Hautes Etudes en Sciences Sociales. p.193-212. 2006.

PETIT, Frédéric.

Observations sur l'éclipse du 18 juillet fait à Briviesca. Compte Rendu de l'Académie des Sciences, Paris, t.51, p.389-394. 1860.

PETIT, Frédéric.

Réponse à la note de M. Leymerie. Mémoires de l'Académie Impériale des Sciences, Inscriptions et
Belles-Lettres de Toulouse, Toulouse, 4. series, t.2, p.289-296. 1853.

PETIT, Frédéric.

Détermination de la longueur du pendule à secondes et de l'intensité de la pesanteur à l'observatoire de Toulouse. Mémoires de l'Académie Nationale des Sciences, Inscriptions et Belles-Lettres de Toulouse, Toulouse, 3. series, t.7, p.87-141. 1850.

\section{PETIT, Frédéric.}

Méthode pour déterminer la parallaxe et le mouvement des bolides. Mémoires de l'Académie Nationale des Sciences, Inscriptions et BellesLettres. Toulouse, 3. series, t.5, p.53-107. 1849a.

PETIT, Frédéric.

Sur la densité moyenne de la chaîne de Pyrénées, et sur la latitude de l'observatoire de Toulouse. Compte Rendu de l'Académie des Sciences. Paris, t.29, p.729-734. 1849b.

PETIT, Frédéric.

Détermination de la latitude du nouvel observatoire de Toulouse et de l'influence que la chaîne des Pyrénées exerce sur cet élément. Mémoires de l'Académie Royale des Sciences, Inscriptions et Belles-Lettres de Toulouse, Toulouse, 3. series, t.3, p.257-270. 1847a.

PETIT, Frédéric.

Note sur les observations météorologiques faites à l'observatoire de Toulouse. Mémoires de l'Académie Royale des Sciences, Inscriptions et Belles-Lettres de Toulouse, Toulouse, 3. series, t.3, p.39-44. 1847b.

PETIT, Frédéric.

Mémoire sur le bolide du 27 octobre et sur une conséquence remarquable qui paraît résulter de son apparition. Mémoires de l'Académie Royale des Sciences, Inscriptions et Belles-Lettres, Toulouse, 3. series, t.1, p.303-319. 1844.

PORTER, ROy.

Charles Lyell: the public and private faces of sciences. Janus, v.69, p.29-50. 1982.

PORTER, Roy.

Gentlemen and geology: the emergence of a scientific career, 1660-1920. The Historical Journal, London, v.21. n.4, p.809-836. 1978.

PORTER, Roy.

The making of geology: Earth science in Britain, 1660-1815. Cambridge: Cambridge University Press. 1977.

PORTER, Roy.

Charles Lyell and 'The principles of the history of geology'. The British Journal for the History of Science, London, v.9, n.2, p.91-103. 1976. 
RUDWICK, Martin.

Geological travel and theoretical innovation: the role of 'liminal' experience. Social Studies of Science, v.26, n.1, p.143-159. 1996.

SHINN, Terry; RAGOUET, Pascal.

Controverses sur la science: pour une sociologie de l'activité scientifique. Paris: Raison d'Agir. 2005.

VINCK, Dominique.

Sciences et société: sociologie du travail scientifique. Paris: Armand Colin. 2007.

\section{$\rightarrow \rightarrow \rightarrow<<<$}

